\title{
THE HOLOCENE AND UPPER PLEISTOCENE POLLEN SEQUENCE OF CARIHUELA CAVE, SOUTHERN SPAIN
}

\section{SEQUENCE POLLINIQUE DE L'HOLOCÈNE ET LE PLÉISTOCÈNE SUPÉRIEUR À LA GROTTE DE LA CARIHUELA, SUD-EST DE L'ESPAGNE}

\author{
Santiago FERNÁNDEZ ${ }^{1}$, José S. CARRIÓN ${ }^{1}$, Noemí FUENTES ${ }^{1}$, \\ Penélope GONZÁLEZ-SAMPÉRIZ ${ }^{2}$, Encarna MONTOYA ${ }^{1}$, Graciela GIL ${ }^{3}$, \\ Gerardo VEGA-TOSCANO ${ }^{4}$, José A. RIQUELME ${ }^{5}$ \\ ${ }^{1}$ Departamento de Biología Vegetal, Facultad de Biología, Universidad de \\ Murcia, Campus de Espinardo, 30100 Espinardo, Murcia, Spain \\ ${ }^{2}$ Instituto Pirenaico de Ecología-CSIC. Av/ Montañana n 1005, 50059 Zaragoza, \\ Spain \\ ${ }^{3}$ Departamento de Biología, Facultad de Ciencias, Universidad Autónoma de \\ Madrid, 28049 Cantoblanco, Madrid, Spain \\ ${ }^{4}$ Departamento de Prehistoria, Facultad de Geografía e Historia, Ciudad \\ Universitaria, 28040 Madrid, Spain \\ ${ }^{5}$ Departamento de Prehistoria y Arqueología, Facultad de Filosofía y Letras \\ Campus Universitario de Cartuja s/n, Universidad de Granada, 18071 Granada, \\ Spain \\ Correspondence author: carrion@um.es \\ Web: http://www.jscarrion.com \\ Phone 34968364995 \\ Fax 34968364995
}




\section{Abstract}

A new pollen sequence (ca.15,700-1250 yr BP) is presented for three stratigraphical sections of Carihuela Cave (Granada, southeastern Spain), thus completing a record that covers from the last Interglacial to late Holocene. The Lateglacial is characterized by open landscapes with junipers and early colonisation of Quercus, while the Holocene is depicted by mixed oak forests, with a diversity of broad-leaf trees and scrub, which decrease after ca. 5470 yr BP synchronously with the expansion of xerophytes and occurrence of indicators of anthropogenic disturbance. The whole pollen record of Carihuela fits into the general trends described for reference pollen sites of southern Europe, including Padul in the province of Granada, and other sequences from Mediterranean Spain, through which the heterogeneity of environmental change increases from mid to late Holocene. We conclude that, in contrast with other regions of Spain, deciduous Quercus-dominated forests are very old in eastern Andalusia, thus conflicting with floristic phytosociological models of vegetation change that imply that monospecific $Q$. ilex/rotundifolia woodlands are the potential mature forest in the region. Dating results suggest that the last Neanderthals of Carihuela lived between ca. 28,440 and 21,430 yr BP, which agrees with the postulation that southern Spain was the latest refugium for this human species in Europe.

\section{Résumé}

On présente une nouvelle séquence pollinique (ca.15,700-1250 yr BP) provenant de trois sections stratigraphiques de la Grotte de la Carihuela 
(Granada, sud-est de l'Espagne), qui complète le période compris entre le dernier Interglaciel et l'Holocène Récent. Le Tardiglaciel est caractérisé par un paysage ouvert avec des genévriers et une colonisation précoce de Quercus, tandis que l'Holocène est représenté par une chênaie mixte avec diverses planifoliés et arbustes, qui diminue après le ca. 5470 yr BP au même temps qui arrive une expansion de xérophites et l'apparition d'indicateurs anthropiques. La séquence de La Carihuela est en accord avec les données palynologiques générales des grands sites du sud de l'Europe, comme celui de Padul à la province de Granada, ou quelques autres de l'Espagne Méditerranéenne, malgré la grande variabilité du changement paléo-environnemental qui va augmenter à partir de l'Holocène Moyen et Récent. On peut dire en conclusion que, au contraire que en autres régions de l'Espagne, la forêt de Quercus caducifoliée est dominante à l'est de l'Andalusie depuis long temps, malgré les modèles phytosociologiques de l'évolution de la végétation qui présentent des formations mono spécifiques de Q. ilex/rotundifolia comme la forêt potentielle mûre à la région. Les dates sugère que les derniers Neanderthales de la Grotte de la Carihuela vivaient encore pendant le ca. 28,440 et le 21,430 yr BP, en accord avec l'hypothèse qui propose le sud de l'Espagne comme le dernier refuge pour ces humains en Europe.

Mots-clés: biogéographie historique, paléoécologie, histoire de la végétation, Pléistocène Supérieur, Holocène, Espagne

\section{Introduction}


Palynological investigations in Carihuela Cave started with Carrión (1992)'s work on sediments from five stratigraphical sections containing Middle Palaeolithic artefacts. Pollen spectra showed millennial-scale changes in the representation of Pinus, Poaceae and Artemisia, and depicted a sequence of Pleistocene vegetation landscapes which would have oscillated between an arboreal vegetation with Pinus and mesothermophilous taxa, and a herbaceous type suggestive of cold stadial conditions.

Carrión et al. (1998) added two late Pleistocene pollen diagrams to the former sequence. Overall, that study reinforced the chronostratigraphical framework by Vega-Toscano et al. (1988), although it was necessary to reconsider the oak-dominated Unit VIla, and move it from interpleniglacial to interglacial, on the basis of a Th/U date of around 117,000 yr BP. Thus, Carrión et al. $(1998,1999)$ postulated the occurrence of (i) a Quercus and Olea-dominated interglacial (ii) a preWürmian phase with alternation of forest and steppe, (iii) two Pleniglacial maxima with steppic vegetation and the disappearance of thermophytes, (iv) an interpleniglacial episode beginning at ca. 45,200 yr BP, with Pinus forests and continuous occurrence of mesothermophilous taxa, (v) a poorly defined Late- Glacial, with a suggestion of Quercus colonization.

Here we present a new radiocarbon dated, Late Glacial to Holocene pollen record, together with dating for some Pleistocene beds studied in Carrión (1992). This new study completes the palaeoenvironmental record, and covers a time span from the Eemian up to the last millenium.

\section{Setting and modern vegetation}


Carihuela cave is located $45 \mathrm{~km}$ northeast of Granada city in eastern Andalusia, southern Spain. It is situated on the north slope of the Sierra Arana Mountain in the valley of the southwesterly flowing Río Piñar (Fig. 1). The cave opening faces north, is situated on the south side of the valley at approximately $3^{\circ} 25^{\prime} 47^{\prime \prime} \mathrm{W}, 37^{\circ} 26^{\prime} 56^{\prime \prime} \mathrm{N}$, and is $1020 \mathrm{~m}$ above sea level.

Carihuela is just one of the several caverns located in the area, with the companion Cueva de las Ventanas being renowned because of speleo-turism (Riquelme 2002). These caves honeycomb a hill upon which a Moorish castle stands. It is this castle which gave rise to the name of the hill, El Castillo (Fig. 1). This hilltop, as well as the caves on its hillside, has a commanding view of the surrounding countryside.

Modern landscape has been altered by anthropogenic activities. Most of the present area around Píñar is utilized for agriculture. Some of the land is under orchards, but the overriding portion is tilled and mainly under wheat, and to a smaller extent under barley. Olives and wine grapes have been cultivated in the area probably since the Early Bronze Age or earlier (Wigand 1978). Citrus and Prunus orchards are recent introductions.

Local forests are characterized by the evergreen oak Quercus rotundifolia, with the semi-deciduous $Q$. faginea in areas with the most humid soils. Q. rotundifolia dehesas are also a common feature of local landscapes. Mixed oak and pine forests are better preserved at higher elevations, primarily along the ridge and on the slopes of the Sierra Arana to the south, but a few other isolated forested areas occur to the 
southwest and north of Piñar and to the west of Iznalloz beyond the Río Cubillas (Carrión 1992). A scrub stage with Quercus coccifera is more common, with Pistacia lentiscus, Phillyrea angustifolia, and Olea europaea in thermic situations (Carrión 1990). Relics of Pinus sylvestris and $P$. nigra forests are found in the region above $1600-1800 \mathrm{~m}$. It is worth stressing that floristically-based phytosociological models (e.g. Rivas-Martínez 1987) contend that potential vegetation on the hills and plains around the Piñar River is a monospecific Q. rotundifolia forest.

\section{Cave description}

Carihuela Cave has three entrance ways, which join after a short distance to form a single chamber with a corridor continuing deeper into the hillside. The cavern axis is oriented in a generally south-easterly direction from the main entrance (Fig. 2) (Vega-Toscano 1988). The largest entrance chamber, Chamber III (CIII), is about $13 \mathrm{~m}$ long and 4 to $6 \mathrm{~m}$ wide, and is connected on the east by a corridor leading to Chambers I and II.

At the south end of Chamber III a corridor about 2-3 $\mathrm{m}$ in width opens into Chamber IV (CIV). This chamber is about $7 \mathrm{~m}$ in length and about the same in width. It is in this chamber and the corridor leading to it that most of the excavations pertinent to this study were carried out (Fig. 2). To the south wall of Chamber IV, a large and easterly, downward opening connects to Chamber $\mathrm{V}(\mathrm{CV})$. At this point, however, the slope of the cavern floor rise steeply upward towards the far end of CV, which southern part is illuminated by light entering through a chimney. This is the 
place of entry for the rock-fall talus cone which occupies much of this chamber.

\section{Excavation findings}

Archaeological exploration in Carihuela has episodically been conducted since the fifties (Spahni 1955), although unfortunately most of the results remains unpublished. Holocene deposits were excavated by Pellicer (1964a, 1964b), who described a series of Neolithic and Bronze Age industries in CIV. Between 1969 and 1971, three excavations were conducted by H. T. Irwin and R. Fryxell, Washington State University (WSU) and M. Almagro, Complutense University of Madrid (Almagro et al. 1970, Garralda 1970). WSU archaeological research was undertaken both in the Exterior Area (AE) as in CIII and CIV (Fig. 2).

From 1979 to 1992, a multidisciplinary project was co-ordinated by G. Vega-Toscano, Madrid. Vega-Toscano et al. (1988) described 12 lithostratigraphical units in the whole cave infill, comprising Units XII-III of Pleistocene age, and Units II-I of Holocene age (Fig. 2). Units XII and XI are peaty clay containing stalagmitic crusts and calcium carbonate pseudomycelia, with scanty faunal remains, mainly turtle. Units $X$ to VIIb comprise blocks and angular clasts in clayey silt, eventually sandy clays. Faunal remains are characterized by Equus caballus cf. germanicus, Cervus elaphus, Bos primigenius, Dicerorhinus kirchbergensis, Microtus nivalis and Allocricetus bursae (Ruiz-Bustos \& García Sánchez 1977). Unit $\mathrm{VI}$ is again characteristically organic, with silty clays, charcoal, and calcareous concretions, with predominance of lagomorphs and carnivores 
(Canis, Ursus, Panthera, Vulpes, and Crocuta). Unit V to III comprise angular clasts, with calcium carbonate precipitation being common across IV and III. Microtus arvalis becomes more common, while lagomorphs and carnivores remain important among the faunal remains. Units II and I are clays with abundant hearths, and Unit II containing gravels.

Paleontological findings include bone remains of Lagomorpha (Lepus, Oryctolagus), Rodentia (Eliomys, Arvicola, Pitymys, Sylvaemus), Carnivora (Canis, Vulpes, Genetta), Equidae, Suidae, Cervidae, and Bovidae (Ovis, Bos, Capra) (Wigand 1978).

The relative importance of eolian, fluvial and biotic transport as sediment sources at Carihuela has apparently varied through time (Carrión et al. 1999). Because of the north facing and overhanging situation of the cave opening, eolian transport may have been present all the time introducing wind-blown silt and clay but nowhere inside the cave uniform sedimentary structures are found that characterize eolian transport (Davis 1990). Considering the particle features, water transport could have been important in Units XII, XI, VIII, VI, and II-I (Carrión 1992). Biotic transport is evident in Units VII and VI (Vega-Toscano 1988, Carrión et al. 1998). On the other hand, cave spall depending on internal weathering of walls and roofs have been a source of sediment in Units X, $\mathrm{VII}, \mathrm{V}$ and III, which coincided with stadial stages in the pollen sequence. Lithic implements of Units XII to V are typical of the Mousterian. In its uppermost part, unit IV displays a Mousterian-like industry without leptolithic transformation (Middle Palaeolithic s.l.) (Vega-Toscano 1993). Unit III contains Upper Palaeolithic tools. Units II and I are mainly 
Neolithic, with Bronze Age materials in the uppermost Unit I. The bulk of the materials retrieved from Chamber IV and $\mathrm{V}$ consists of pottery sherds. In addition, there are blades, numerous items of worked bone, stone, bone and shell beads, shell pendants, schist and shell bracelet fragments, flint sickle blades, silver and gold rings, polished blades, grinding stones, marble and bone idols, bronze daggers, bone of sheep, goat, cattle and pig, and carbonized grains of wheat and barley (Pellicer 1964a, Wigand 1978).

Human remains in Units VIII, VI, V and lowermost levels of Unit IV are attributable to the Neanderthals; and the Units III-I and uppermost beds of Unit IV to anatomically modern man ("Moderns") (García-Sánchez 1960, Vega-Toscano 1988). Neanderthal remains include fragments of parietal and frontal bones of both adults and children. Bone remains from Moderns include cranial and tibial fragments during the Pleistocene and a diversity of individual and collective burials during the Neolithic and Bronze Age levels (Fig. 8). Human osteological remains are in fact, abundant in $\mathrm{CIV}$ and $\mathrm{CV}$, but unfortunately in most cases severely fractured (Wigand 1978).

\section{Chronology}

Several series of thermoluminescence dates were provided by Fremlin (1974), Göksu et al. (1974), and Vega-Toscano (1988), but lack exact stratigraphical origin, and uniquely refer to the nature of material and industrial typology (Tables 1 and 2). In any case, what remains clear is (i) that they show a time-span of about 70,000 years for materials extracted 
from units XI to III, ranging between approximately 82,500 and $11,200 \mathrm{yr}$ $\mathrm{BP}$, and (ii) that considering the Late Palaeolithic tools associated with TB6, TB8b, and TB7, it is likely that the dates in these units represent materials of units IV and III in Chamber IV.

During the course of investigations by Carrión et al. $(1998,1999)$ and this work, several samples of sediment from different sections have been submitted for radiocarbon (mainly organic clays) and ${ }^{230} \mathrm{Th} /{ }^{234} \mathrm{U}$ (mainly breccias) dating (Tables 3,4$)$. The results show that

(i) Unit VIla was formed during the last interglacial stage, which would mark the onset of the pollen sequence.

(ii) The interpleniglacial episode defined by the deposition of clays during Unit VI started around 45,000 yr BP and ended before 28,500 yr BP, broadly correlating with OIS 3 (ca. 48-26 kyr BP), and placing the thermoclastic, xerophyte-dominated Units VIIb and $\mathrm{V}$ in episodes of OIS 4 and 2 respectively.

(iii) Last Neanderthals of Carihuela lived between ca. 28,440 and $21,430 \mathrm{yr}$ BP, which agrees with the postulation that southern Spain was the last refugium for this human species in Europe. In fact, the pattern of disappearance of Neanderthals across the Iberian Peninsula suggests a strong north to south pattern.

(iv) Sediments building CIV sections 3, 4 and 5, which are placed within Pellicer (1964a)'s excavation area, were deposited between ca. 15,700 and $1250 \mathrm{yr}$ BP (Table 3). Dating of these sediments suggest that Unit III is mainly Lateglacial, and Units II and I are postglacial, as suggested by Vega-Toscano (1988). 


\section{Pollen-analytical methods}

Carrión (1992) studied palynology of Units XII to IV, although the Unit XII and the lowermost levels of XI contained no pollen. Carrión et al. (1998) carried out pollen analysis of two profiles from CIV (1 and 2) comprising Units VI to III (Fig. 2). Here we present pollen analysis of three additional sections from CIV situated in the transition towards CV. These profiles, referred as CIV sections 3, 4 and 5, embrace Units III to I (Fig. 2). In total, 87 sediment samples were analyzed, including 10 samples for CIV Section 3 (samples 87-78), 11 for CIV Section 4 (samples 77-67), and 66 for CIV Section 5 (samples 66-1). Sample 1 was made of superficial bat guano and was not considered for this study. Samples $6,7,10,11,39,40$, 47, 48 and 60 from CIV Section 5, samples 70-72 from CIV Section 4, and sample 80 from CIV Section 3 lacked pollen.

Samples for pollen analysis were taken according to lithological features at irregular intervals of to 4 to $10 \mathrm{~cm}$. Laboratory treatment was performed following conventional $\mathrm{HF}, \mathrm{HCl}, \mathrm{KOH}$ method and Lycopodium clavatum tablets containing a known quantity of spores were added to each sample prepared to enable a calculation of pollen concentration. Pollen grains were concentrated by means of the heavy-liquid flotation method outlined by Girard and Renault-Miskovsky (1969). Residues were mounted in silicone oil.

Pollen identification and counting followed standard procedures. Any damaged grains of which identification were not secure, were placed in an "indeterminable" category. Percentages of each taxon for each 
sample were based on a pollen sum of 244 to 712 grains (mean 405) excluding cryptogam spores. Between 10 and 41 (mean 24, total 52) pollen taxa were identified.

Pollen percentage and concentration diagrams include pollen spectra relative to CIV section 3 (below), CIV section 4 (middle part), and CIV section 5 (above) (Figs. 3-5). Local pollen assemblage zones were determined after visual inspection of the variation in the dominant pollen taxa. Sterile samples are represented in the pollen diagrams as breaks in the pollen curves.

A synthetic pollen diagram for the whole sequence of Carihuela is presented in Figure 6 taking into account the lithostratigraphic correlation of Vega-Toscano et al. (1988), but moving the relative position of VIla (zone R) down to the basis, according to its ${ }^{230} \mathrm{Th} /{ }^{234} \mathrm{U}$ chronology (Table 3). As in the course of past investigations pollen analysis for some lithostratigraphic units was repeated (Carrión 1992, Carrión et al. 1998), it was necessary to exclude overlapping spectra in the construction of the synthetic diagram. Thus, although curves in Figs. 3-6 seem to be continuous, one should bear in mind that hiatuses may occur at the section changes and at several other stages of the sequence. In order to avoid confusion with Carrión (1992)'s zone R (Unit VIIa), we here propose a new nomenclature for the pollen zones (Figs. 3-6).

\section{Results: completing the pollen record}

\subsection{General features of the new sequences}


The main pollen contributors to the pollen sequences of CIV Sections 3, 4 and 5 are Quercus, Poaceae, Asteraceae, and to a lesser extent, Pinus, Juniperus, Artemisia, Lamiaceae, Helianthemum, and Pteridophyta. In comparison with the pollen sequences of the sections studied up to now in CIII (Carrión 1992) and CIV (Carrión et al. 1998), Quercus reaches considerably higher values while Pinus, Artemisia and Ephedra are generally lower. Some minor types appear for the first time such as the indicators of agriculture Vitis, Polygonum aviculare type and Cerealia.

\subsection{Pollen stratigraphy}

The new pollen records comprise pollen zones 18 to 22 (Figs. 3-5). Zone 18 includes pollen spectra 87-83 from CIV Section 3. Maxima for juniper pollen (c. 6\%) are recorded, as well as low percentages of Pinus (below 4\%), while deciduous Quercus shows an increase from 8 to $16 \%$ and evergreen Quercus from 3 to 9\%. In contrast, Poaceae pollen decreases from its high amounts at the base (52\%). Artemisia pollen is relatively high (10\%), although yet declining towards the end of the zone. Continuous occurrences of Corylus, Fraxinus, Ulmus, Betula, Rhamnus, Pistacia, Phillyrea, Cistus, Salix, Ephedra fragilis, Olea, Ononis and Hedera are recorded. Lamiaceae is especially prominent (9-4\%) among NAP (nonarboreal pollen)

Zone 19 includes pollen spectra 82 to 78 from CIV Section 3. A progressive increase of Quercus pollen (32\% for deciduous type and 17\% for evergreen) is shown, while Poaceae and Artemisia continue with decreasing trends. Pine pollen representation is low, not exceeding $4 \%$. 
Corylus, Betula, Juglans, Fraxinus, and Salix occur among the AP (arboreal pollen). Relatively large values of Asphodelus (7\%) and Lamiaceae (6\%), and a diversity of herbs are indicative of heliophytic vegetation within a generally open forested landscape. Forests are dominated by oak species with a good variety of other trees and a diverse woody understorey of Pistacia, Phillyrea, Rhamnus, Olea, Cistus, and Viburnum.

Zone 20 (ca. $7700-6910 \mathrm{yr}$ BP) includes pollen spectra 77 to 67 from CIV Section 4. Quercus pollen is predominant, with a maximum value of $36 \%$ for the deciduous type, and $23 \%$ for the evergreen type. Poaceae is generally less abundant than in the preceding zones accounting around 13-6\%. Artemisia, Juniperus and Pinus continue to be secondary pollen contributors to this pollen zone. AP includes Castanea (1.3\%), Juglans (0.6\%), Ulmus, Corylus, Betula and Alnus, among others, but never surpassing 0.4\%. Ericaceae, Rhamnus, Pistacia, Cistus, Olea (2.9\%) and Phillyrea do not show visible changes respecting the former zone. Genisteae shows a peak (3.8\%) in this zone. Ephedra distachya type disappears from the pollen record, while Ephedra fragilis appears eventually. Several NAP types are relatively prominent, like Helianthemum (7\%), Apiaceae (3.5\%), Asphodelus (3.7\%), Geraniaceae (3\%), Plantago (1.9\%) and Pteridophyta (2.9\%). Other types decrease in relation to the former zone, such as Lamiaceae(3-0.7\%), Chenopodiaceae(2.5-0.7 \%), Caryophyllaceae (4-0.7\%), Brassicaceae (1.5-0.3\%) and Rubiaceae (1.7$0.7 \%)$. 
Zone 21 (ca. 6260-5470 yr BP) refers to the samples 66-13 from CIV Section 5. Palynological features are very much like those of the former Zone 20. We establish two zones instead of a single zone because there is a hiatus in the section between ca. 6910 and $6260 \mathrm{yr} \mathrm{BP}$ that belong to different sections from the CIV excavation grid (Fig. 2). Deciduous Quercus are again predominant with peaks of $43 \%, 42 \%$ and $39 \%$. This type oscillates throughout the zone, in the same way as the evergreen Quercus type, with maxima values around $28-30 \%$ and minima of $14-15 \%$. Poaceae also shows fluctuations, but generally increase to a percentage of $48 \%$ in sample 22. Poaceae maxima coincide with Quercus lows in most of the zone. It is worth mentioning the abundance of Asteraceae pollen after c. 5690 BP, with values consistently above $30 \%$. This uppermost part of zone 21 is also where Poaceae shows its highest frequencies. This change involves a reduction of the fern spores component. Characteristically, these variations in Asteraceae, Poaceae, and Pteridophyta are visible in the concentration curves (Fig. 5).

Zone 22 (ca. 5470-1250 yr BP) includes pollen spectra 12 to 2 from CIV Section 5. A first particularity of this zone is the increase of Pinus and Juniperus up to $10 \%$ and $3.8 \%$ respectively, accompanied by a marked decrease in deciduous oak pollen (4-7\%), and to a smaller extent in evergreen oak pollen (8-17\%). Poaceae shows persistently high percentages of about 30-33\%. Artemisia increases slightly (6\%). Corylus, Betula, Buxus and Myrtus disappear from the pollen record, while Juglans (0.8\%), Genisteae (3\%), Chenopodiaceae (3\%), and Olea (3\%) increase. This zone is also characterized by the exclusive occurrence of Vitis 
(0.4\%), Cerealia (1.7\%), Polygonum aviculare type (0.4\%), and maximum values of Plantago around 3-4\%.

Unfortunately, a precise attribution of Pellicer (1964a, 1964b)'s archaeological materials (Neolithic and Bronze Age's) to the described pollen stratigraphy is not feasible since this author hardly gave sedimentological descriptions of the archaeological beds, and, indeed, his published profile for CIV in Pellicer (1964a) is quite different to the drawing by Vega-Toscano et al. (1996) and the section observed by us during the pollen sampling in 1999. It is, however, clear from these publications and the chronology presented here that the zones 19- 22 are dominated by Neolithic materials, with Bronze Age materials mixed in the superficial zone 22.

\subsection{Taphonomical considerations}

It is worth mentioning that several peaks of indeterminable pollen coincide with decreases in the number of pollen taxa, and eventually with relatively high values of Asteraceae pollen, for instance in the uppermost zone 21 (Fig. 5). At first, this could suggest differential preservation. However, considering the whole sequence, a scenario of selective preservation and sediment decomposition seems unlikely. Firstly, we see that several peaks of indeterminable pollen sometimes coincide with high pollen concentrations even in the context of high sedimentation rates. Secondly, because between 5470 and 1250 yr BP, pollen concentration decreases together with declines of indeterminable and Asteraceae pollen, and increases of pollen taxon diversity. Thirdly, there are generally similar 
fluctuations in the curves of pollen concentration (Fig. 5) and pollen percentages (Figs. 3-4), suggesting that the events to be described are real, rather than statistical artefacts. Fourthly, because, it is apparent that the declines in concentration are not universally related to increased values of indeterminable and/or Asteraceae types (Fig. 4). Finally, the relationships between these indicators of reliability are very complex, and may vary from layer to layer (Carrión et al. 1999, Navarro et al. 2000, Carrión 2002b). Post-depositional processes associated with cave pollen spectra are poorly known, but to-date experimental work suggests a great deal of stochastic tendencies (Burney \& Burney 1993, Navarro et al. 2001).

The studied sequences show acceptable pollen taxa diversity. A total of 52 pollen types have been recognized. For the whole sequence, 87 pollen types have been identified. Differently to CIV Sections 1 and 2 (Carrión et al. 1998), there are no palynological indicators (e.g. algal spores) of water transport in these pollen diagrams, although episodically this means of transport cannot be excluded for sedimentation or erosion in some parts of the cave.

\section{Discussion}

\subsection{Lateglacial and Holocene palaeoenvironments}

The new pollen record starts at ca. 15,700 yr BP depicting the onset of the Late Glacial, which has been dated in Padul at ca. 15,200 yr BP (Pons \& Reille 1988). A grass-dominated open landscape can be inferred from the 
pollen spectra of zone 18 , although there is a noticeable diversity of trees and shrubs, including mainly oaks, both deciduous and evergreen, and mesothermophilous components (e.g. Olea, Corylus, Fraxinus). It is reasonable to infer the existence of juniper-dominated parklands in the regional plateaux (Carrión et al. 2004).

The Lateglacial sequence of CIV Section 2 was also characterized by a pollen curve of Juniperus, with the presence of Betula, and indicators of climate improvement such as evergreen and deciduous Quercus, Fraxinus, Acer, Corylus, Salix, Rhamnus, Cistus, Viburnum, Olea europaea and Myrtus communis, which occur for the first time (Carrión et al. 1998). There is no signal for the Younger Dryas cold event in zone 18, probably because the Late Glacial CIV 3 section contains hiatuses. A pollen signal for this climatic phase was, however, visible in CIV section 2 (Carrión et al. 1998).

These lateglacial pollen spectra allow us to place the coprolite (Crocuta crocuta) pollen record of Las Ventanas in the Younger Dryas. This was anticipated in Carrión et al. (2001c) on the basis of a coprolite date of ca. 10,670 yr BP. A mosaic landscape was inferred comprising grasslands, steppes of Artemisia with junipers, pine forests and patches of oak forests with other temperate and Mediterranean trees and shrubs like Betula, Abies, Corylus, Alnus, Acer, Taxus, Myrtus, Olea, Pistacia, Ephedra fragilis, and Rhamnus.

The following stage, pollen zone 19 , involves a regression of the juniper formations, a feature that marks the beginning of the Holocene in many regions of Iberia (Peñalba et al. 1997, Carrión 2002a). Pollen zones 
20 (7700-6910 yr BP) and 21 (6260-5470 yr BP) indicate a clearly arboreal early to mi-Holocene palaeo-vegetation, characterized by the dominance of broad-leaf species within a mixed oak forest ecosystem with diversity of trees and understorey.

The most recent phase of the sequence, zone 22 (ca. 5470-1250 yr $\mathrm{BP})$, represents a mid to late-Holocene mesophyte depletion with local extinction of several broad-leaf species, and opening of the landscape. Yet, oaks dominated the landscape. Xerophytes and indicators of agriculture and expansion of grazing in the region are recorded together with more pines and junipers. The arboreal cover also experiences a reduction.

\subsection{The whole sequence}

After these results, the main features of the Carihuela palaeoenvironmental record are: (i) a last Interglacial Olea/Quercusdominated stage (Zone 1) with a diversity of other trees and shrubs, (ii) an interval (Zones 2-5), perhaps equivalent to the Pre-Würm of Padul (Pons \& Reille 1988), with alternation of Artemisia and forest taxa that included oaks and pines, (iii) several full-glacial maxima (mainly in Zones 9 and 1315) with forest depletion, dominance of Artemisia, Poaceae, Chenopodiaceae and Ephedra distachya type, and sedimentological and paleontological indicators of climatic shifts to increased dryness, (iv) an inter-Pleniglacial episode (Zones 10-12) with pine forest developments (v) a Late Glacial stage (Zone 18) with oak colonisation, (vi) a Holocene phase (Zones 19-22) featured by mixed oak forests with decreasing 
diversity of broad-leaf trees and increasing xerophytes and anthropophytes across the transition from mid to late Holocene (Fig. 7).

It cannot be stressed enough that, in order o compare lithological and palaeobiological evidence in Carihuela, the best criteria are the nature and composition of the pollen assemblages rather than the pollen percentages or concentrations (Fig. 7). Thus, as shown by Carrión et al. (1998), the number of mesothermophilous taxa conforms better with lithological and faunal events than the vegetation types. For instance, thermoclastic scree was particularly abundant in Units VIIb and V, where fossil rodents such as Microtus arvalis that indicate cold conditions, are noticed and where pollen spectra argue for steppe-like vegetation without thermophilous elements. In contrast, the occurrence of carbonate concretions is apparent in the basal breccia and Units XI, VI, IV-III, and II-I where pollen spectra contain thermophilous taxa.

Ever since the pioneering work on Carihuela (Carrión 1990), the assessment of cave palynology has changed on the basis of some experimental results on aerial pollen deposition (Burney \& Burney 1993, Coles \& Gilbertson 1994, Hunt \& Rushworth 2005), surface sedimentation (Navarro et al. 2000, 2001), speleothem development (McGarry \& Caseldine 2004), and faecal accumulation of a diversity of animals (Carrión 2002b, Pearson \& Betancourt 2002). In the context of these investigations, it seems that Carihuela Cave is well orientated as a site for pollen analysis, because of (i) the occurrence of three large entrances favouring pollen input through air circulation, (ii) the occurrence of sedimentary strata covering the full-glacial stages, which are usually 
represented as gaps in cave infillings and as palynologically sterile loess in peaty basins (Carrión \& Van Geel 1999), (iii) excavations opened several profiles where lateral comparison of pollen spectra can be performed, (iv) good pollen preservation and substantial pollen concentration, and (v) the possibility of correlation with cultural phases. On the other hand, the reliability of the pollen assemblages is supported by the existence of equivalent rises and falls in the curves of pollen concentrations and percentages, and relatively low frequencies of indeterminable palynomorphs (Figs. 3-6).

In addition, the Carihuela pollen record fits into the general trends described for pollen records of reference sites of the Mediterranean Basin (Tzedakis et al. 1997, Jalut et al. 2000, González-Sampériz 2004, Roberts et al. 2004, Willis \& van Andel 2004). In this sense, the most pertinent case is Padul (Pons \& Reille 1988), a pollen site situated to the south in the Granada province, within a slightly warmer and less continental climate. Like Carihuela, the Padul pollen record includes Eemian and Holocene phases characterized by forested landscapes of oaks and thermophytes, while the main woods during the Pleistocene stages are pines and junipers, which alternate with herbaceous types, eventually Artemisia and Poaceae as main pollen contributors during full-glacial peaks (Fig. 8). Both sequences can be compared as follows:

(i) The interglacial Padul 2 zones a-j ("PreWürm" in Pons \& Reille1988) as equivalent to Carihuela zones 1-5, although Olea and Artemisia are comparatively more important in Carihuela. It remains a possibility that the Padul 2 zones a-j are equivalent to Carihuela zone 1. 
(ii) The full-glacial Padul 3 zones a-f $(29,300-15,200 \mathrm{yr}$ BP) as equivalent to Carihuela zones 14-17 (28,480-15,700 yr BP).

(iii) The Late Glacial Padul 3 zones g-I (15,200-10,000 yr BP) as equivalent to Carihuela zone 18 (15,700-).

(iv) The postglacial Padul 3 zones m-t (before $8200-4450$ yr BP) as roughly equivalent to Carihuela zones 19-21 (10,000-5470 yr BP).

A more detailed correlation is not feasible because there must be some differences related with pollen taphonomy and local physiography, and both sequences lack acceptable chronological control for the early Upper Pleistocene zones.

The early oak colonisation in Carihuela and Padul during the Late Glacial suggests the proximity of glacial refugia for evergreen and deciduous Quercus together with other trees and shrubs. The Siles pollen record (Carrión 2002a) is especially relevant to demonstrate the continuous presence of arboreal populations in the Betic mountain ranges during full glacial episodes. Tree survival would have been especially important in mountain ranges like Sierra Nevada and Sierras Mágina, Arana, Segura and Cazorla. The sharp orography of these massifs would have allowed rapid altitudinal displacements of tree populations in response to climatic pulses. Other data suggesting that these cordilleras included important tree reservoirs during the last glacial stage can be found in the present genetic structure of European tree populations (Arroyo-García et al. 2001, Olalde et al. 2002, Burban \& Petit 2003, 
Jiménez et al. 2004), and pollen sequences from caves and rockshelters (Dupré 1988, Carrión et al. 1995, 2003a).

Nevertheless on the basis of the similarities between Carihuela and Padul, neither of these sites should be considered representative of any general trend of Late Glacial and Holocene forest succession for southern Iberia. The available pollen records offer a picture of great spatial heterogeneity, and do not show persistent trends through time. Firstly, oak invasion may not take place during the Late Glacial, or even the early Holocene, but may rather be delayed until the mid-Holocene, such as in Navarrés, Valencia (Carrión \& Dupré 1996, Carrión \& Van Geel 1999), Villaverde, Albacete (Carrión et al. 2001a), and Gádor (Carrión et al. 2003b) and San Rafael, Almería (Pantaleón-Cano et al. 2003). Secondly, pine forests may dominate the whole Holocene series such as in many sites of central Spain (García-Antón et al. 1986, Franco et al. 2001), Iberian System (Peñalba 1994, Stevenson 2000), Valle del Ebro (Stevenson et al. 1991, González-Sampériz 2004), and the semi-arid south-eastern region (YIl et al. 2003). A third scenario is that Quercus and Pinus remain co-dominant during most of the Holocene, like in Elx and Salines, Alicante (Burjachs et al. 1997), and Torreblanca, Castellón (Pérez-Obiol et al. 1994). This diversity of vegetational developments involves the occurrence of episodic and abrupt vegetation changes (Carrión et al. 2001b) in contrast to cases of millennial-scale complacency to continental-scale climate change (Carrión 2001). It therefore appears that a particular state of the vegetation is at least partially, influenced by its biotic history rather than merely by the abiotic site properties. 
It is perhaps meaningful that this heterogeneity of environmental change increases from mid to late Holocene in Mediterranean Spain (Dupré \& Renault-Miskovsky 1990, Badal et al. 1994), which strongly suggests that human activities have been of paramount importance to shape current landscapes. Palynological indicators of anthropogenic disturbance are clear in sites of Levante and western Andalusia since the Neolithic (Stevenson \& Harrison 1992, Carrión \& van Geel 1999) while the ecological structure of the landscape is not seriously affected by man until the Argaric period in montane Almería and Murcia (Carrión et al. 2003b), and remains affected by uniquely pastoralism until historical times in highelevation mountain areas of the Betics (Carrión 2002a).

The case with Carihuela is not clear-cut since sediments of the anthropogenic pollen zone 22 are relatively disturbed and the industry for this zone is represented by a mixture of Neolithic and post-Neolithic materials. The faunal record and seed remains in CIV and CV suggests agriculture and animal domestication ever since the Neolithic and especially since the Chalcolithic and Argaric periods (Wigand 1978), and the abundance of post-Neolithic settlements around Iznalloz, Huélago, Campotéjar, Sierra Arana, Río Fardes and Laborcillas (Pellicer 1964a, 1964b, Wigand 1978, Nocete 2001) supports the idea that human impact upon the landscapes may have been relatively intense in the lowlands ever since ca. 4500 BP. Archaeological literature tends to suggest enhanced intensity of human impacts in the region from the Chalcolithic period to the Bronze age, including the occurrence of lowland and midland forest destruction and matorralization (Chapman 1991). 
Palaeoanthracological and carpological evidence has been indicated to testify to wider clearance, increased exploitation of woody species, and advanced pasturage (Rodríguez-Ariza 1995, Buxó 1997), while pollen analyses in open-site excavation beds from river valleys show increased heliophytes, sparser pines, and anthropogenic indicators (Cerealia, Plantago, Polygonum, Vitis) (López-García 1988, Davis \& Mariscal 1994). However, in view of detailed environmental inference, we think that this basis of evidence including site-specific palynology, is probably not the type of data that could provide reliable answers. The problem appears where the spatial scale reaches crucial importance and, therefore, the magnitude of human interference on the eastern Andalusian landscape might be only adequately approached on the basis of specifically-designed projects.

Yet, the pollen sequence presented here can be supported by the Padul one to demonstrate that, unlike other regions of eastern and central Spain, oak forests are very old in eastern Andalusia. The bone of contention with floristic phytosociological models of vegetation change (e.g. Rivas-Martínez 1987, Peinado et al. 1992) could come from the fact that, both in Padul and Carihuela, deciduous oaks are very abundant, if not eventually dominant, since the Lateglacial. Thus, the most parsimonious picture of Holocene pre-anthropic vegetation is one dominated by mixed oak forests with important contribution of pines instead of monospecific Q. ilex/rotundifolia woodlands, as assumed by neontologists. 


\section{Acknowledgements}

We thank constructive comments by S.D. Muller, Louis Scott, and an anonymous referee on an earlier draft of the manuscript. This investigation has been funded by the projects PI-17/00739/FS/01 and PI-00369/FS/04 (Fundación Séneca, Murcia), and REN2003-02499-GLO (Ministerio de Ciencia y Tecnología, Madrid).

\section{Figure captions}

\section{Figures}

Figure 1. Location of Carihuela Cave and the adjacent Las Ventanas Cave in the Monte del Castillo de Píñar, and the Padul peatbog to the west of Sierra Nevada (Granada, eastern Andalusia, Spain).

Figure 1. Localisation de la Grotte de La Carihuela et la Grotte de Las Ventanas, en proximité, au Mont du Castillo de Piñar, et de la tourbière de Padul, à l'ouest de Sierra Nevada (Granada, est de l'Andalusie, Espagne).

Figure 2. Longitudinal section of Carihuela Cave showing the situation of the main chambers, profiles and lithostratigraphical units studied for pollen by Carrión (1992), Carrión et al. (1998) and this paper. Most sediments from $\mathrm{Cl}, \mathrm{CII}$, and $\mathrm{CIII}$ come from the exterior via the north-facing entrances. Infills from CV and most of CIV entered through the chimney situated in the south extreme.

Figure 2. Section longitudinale de la grotte de La Carihuela selon la localisation des principales chambres, profiles et unités litho- 
stratigraphiques qui on été étudiés par la palynologie par Carrión (1992), Carrión et al. (1998), et en ce papier. La plus part des sédiments de Cl, CIl et CIII viennent de l'extérieur via les entrées orientées au nord. Ceux de CV et une bonne part de CIV sont arrivés par la cheminée de l'extrême sud.

Figure 3. Percentage pollen diagram of CIV Sections 3-5. Arboreal pollen. Figure 3. Diagramme pollinique en pourcentages de CIV, sections 3-5. Pollen d'arbres..

Figure 4. Percentage pollen diagram of CIV Sections 3-5. Non-arboreal pollen. Pteridophyta excluded from the pollen sum.

Figure 4. Diagramme pollinique en pourcentages de CIV, sections 3-5. Pollen des herbacées. Pteridophyta ne sont pas inclus.

Figure 5. Concentration pollen diagram of selected taxa for CIV Sections 3-5.

Figure 5. Diagramme avec la concentration pollinique de quelques taxons sélectionnés de CIV, sections 3-5.

Figure 6. Synthetic pollen diagram of Carihuela Cave.

Figure 6. Diagramme pollinique synthétique de la grotte de La Carihuela

Figure 7. Chrono- and biostratigraphical relationships for Carihuela in the context of archaeological findings and human remains. 
Figure 7. Relations entre la chronologie et la biostratigraphie à la grotte de la Carihuela dans le contexte archéologique et de restes humains.

Figure 8. Comparison of the Padul and Carihuela pollen records.

Figure 8. Comparaison entre les séquences polliniques de Padul et La Carihuela 
Table 1. Thermoluminescence dating for Carihuela CIII section 1 (Units XI-III) which became available after the excavations by H.T. Irwin and R. Fryxell of Washington State University (Vega-Toscano 1988)

Table 1. Dates de thermoluminescence de la chambre CIII de la grotte de la Carihuela, section 1 (Unités XI-III), disponibles après les fouilles de H.T. Irwin et R. Fryxell, de l'Université de Washington (Vega-Toscano, 1988).

\begin{tabular}{lccc}
\hline Sample $\mathbf{n}^{\mathbf{0}}$ & $\begin{array}{c}\text { TL estimated } \\
(\mathrm{yr} \text { BP) }\end{array}$ & $\begin{array}{c}\text { Suggested } \\
\text { lithostratigraphy }\end{array}$ & $\begin{array}{c}\text { Suggested } \\
\text { palynozone }\end{array}$ \\
\hline & & III & 18 \\
B48 & $13,400 \pm 600$ & IV & $16-17$ \\
B52 & $19,300 \pm 500$ & IV & 16 \\
B6 & $20,200 \pm 1200$ & IV & 16 \\
B47 & $20,950 \pm 1200$ & V-IV & 16 \\
B43 & $21,100 \pm 1300$ & VI-(V) & $11-13$ \\
B44 & $37,350 \pm 2200$ & VI & 11 \\
B54 & $42,400 \pm 1500$ & VI & 10 \\
B49 & $49,200 \pm 2500$ & X-VIII & $6-8$ \\
B53 & $68,000 \pm 1800$ & XI & $2-5$ \\
B46 & $82,500 \pm 4900$ & & \\
\hline
\end{tabular}


Table 2. Thermoluminescence dating for Carihuela CIII and CIV chambers (Units XI-III) in accordance with determinations by Göksu et al. (1974) and subsequent modifications by Göksu \& K. Sammers (in Davidson 1989). Suggested litho- and palynostratigraphy rely on the archaeological findings in combination with data in Figure 7

\begin{tabular}{lllllll}
\hline Sample $\mathbf{n}^{\mathbf{0}}$ & Göksu et al. & Göksu (thesis) & Davidson 1989 & Archaeology & Suggested & Suggested \\
& $\mathbf{( 1 9 7 4 )}$ & & & & Unit & Palynozone \\
\hline TB7 & $12,000-14,000$ & $13,600 \pm 800$ & 11,200 & Late Palaeolithic & III in CIII 2 & 18 \\
TB6 & $20,000 \pm 3000$ & $20,200 \pm 3000$ & 17,000 & Late Palaeolithic & IV-III in CIV & $16-18$ \\
TB8b & $20,000-21,000$ & $27,000 \pm 1000$ & 23,000 & Late Palaeolithic & V-IV in CIV & 15 \\
TB12 & 39,000 & $27,400 \pm 1000$ & 25,700 & Mousterian & V in CIII & $14-15$ \\
TB2 & 28,000 & $28,000 \pm 1000$ & 27,300 & Mousterian & V in CIII & $14-15$ \\
TB5 & $31,000-35,000$ & $33,000 \pm 1200$ & 25,200 & Mousterian & V in CIII & $14-15$ \\
TB1 & 32,000 & $39,400 \pm 2000$ & 34,000 & Mousterian & VI-V in CIII & $14-15$ \\
TB3 & 46,000 & $57,700 \pm 2500$ & 45,200 & Mousterian & VI in CIII & 10 \\
TB9a & 48,000 & $58,800 \pm 2500$ & 47,800 & Mousterian & VI in CIII & $9-10$ \\
TB8a & 80,000 & - & - & Mousterian & XI in CIII & $2-5$ \\
\hline
\end{tabular}


Table 3. Radiocarbon dating for CIII, CIII AE, and CIV, and Th/U dating for CIII. See archaeological, palaeoanthropological, litho- and palynostratigraphical contexts. ${ }^{\star}=$ published in Carrión et al. (1998)

Table 3. Dates radiocarboniques des niveaux CIII, CIII AE et CIV ; et dates de U/Th du niveau CIII. Réviser les contextes archéologiques, paléoanthropologiques, lithologiques et palyno-stratigraphiques déjà publiés à Carrión et al. (1998)

\begin{tabular}{|c|c|c|c|c|c|c|c|}
\hline $\begin{array}{c}\text { Laboratory } \\
\text { No. }\end{array}$ & $\begin{array}{c}\text { Sample material I } \\
\text { Method }\end{array}$ & Years BP & $\begin{array}{l}\text { Chamber } \\
\text { I Section }\end{array}$ & Unit & $\begin{array}{l}\text { Carrión et al. } \\
(1998)^{\prime} \text { s zone }\end{array}$ & $\begin{array}{l}\text { Pollen Zone } \\
\text { (this paper) }\end{array}$ & $\begin{array}{c}\text { Archaeology } \\
\text { I Human remains }\end{array}$ \\
\hline Beta-141048 & Organic $/{ }^{14} \mathrm{C}$ & $1250 \pm 60$ & CIV 5 & $1-1$ & - & 22 & H. sapiens \\
\hline Beta-141049 & Organic $/{ }^{14} \mathrm{C}$ & $5470 \pm 90$ & CIV 5 & I-1 & - & $21 / 22$ & Neolithic / H. sapiens \\
\hline Pta-9162 & Organic $/{ }^{14} \mathrm{C}$ & $5690 \pm 30$ & CIV 5 & $1-5$ & - & 21 & Neolithic / H. sapiens \\
\hline Pta-9163 & Organic $/{ }^{14} \mathrm{C}$ & $6260 \pm 20$ & CIV 5 & $\mathrm{II}-2$ & - & 21 & Neolithic / H. sapiens \\
\hline Beta-141050 & Organic $/{ }^{14} \mathrm{C}$ & $6910 \pm 70$ & CIV 4 & $\| 1-4$ & - & 20 & - \\
\hline Pta-9166 & Organic $/{ }^{14} \mathrm{C}$ & $7700 \pm 90$ & CIV 4 & II-5 & - & 20 & - \\
\hline Pta-9165 & Organic $/{ }^{14} \mathrm{C}$ & $8130 \pm 100$ & CIV 3 & II-6 & - & 19 & - \\
\hline * Beta-74380 & Organic / AMS & $12,320 \pm 60$ & CIV 2 & III & CIV 2-d & - & Late Palaeolithic / H. sapiens \\
\hline Pta-7892 & Organic $/{ }^{14} \mathrm{C}$ & $15,700 \pm 220$ & CIV 3 & III & - & 18 & Upper Palaeolithic / H. sapiens \\
\hline Pta-8745 & Organic $/{ }^{14} \mathrm{C}$ & $21,430 \pm 130$ & CIII 1 & Uppermost V & M & 15 & Mousterian / Neanderthal \\
\hline Pta-8746 & Organic $/{ }^{14} \mathrm{C}$ & $25,850 \pm 180$ & CIII 1 & Intermediate $\mathrm{V}$ & M & 14 & Mousterian / Neanderthal \\
\hline Pta-8733 & Organic $/{ }^{14} \mathrm{C}$ & $28,440 \pm 240$ & CIII 1 & Basal V & $\mathrm{N}$ & 13 & Mousterian / Neanderthal \\
\hline * Beta-74381 & Organic / AMS & $45,200 \pm 1270$ & CIII AE 1 & Basal VI & $\mathrm{Q}$ & 10 & Mousterian / Neanderthal \\
\hline${ }^{*} \mathrm{UAB}$ & Breccia $/{ }^{230} \mathrm{Th} /{ }^{234} \mathrm{U}$ & $117,000 \pm 41.000$ & CIII AE 3 & VIla & $\mathrm{R}$ & 1 & - \\
\hline
\end{tabular}


Table 4. Radiocarbon ages of bulk sediment samples from Carihuela Cave (ages calibrated using the program CALIB Rev 5.0.1. (Reimer et al. 2004). The calibrated age BP was taken as the midpoint of the 2 sigma probability interval. Calibration data set: intcal.0.4. Copyright 1986-2005. M Stuiver and PJ Reimer.

Table 4. Les dates radiocarboniques ont été obtenues à partir de sédiment total de la Grotte de la Carihuela. Pour calibrer les âges on a employé le logiciel CALIB Rev 5.0.1. (Reimer et al. 2004). Les âges BP calibrés ont été pris au milieu de l'intervalle de probabilité 2 sigma. Série de données pour la calibration: intcal. 0.4. Copyright 1986-2005. M Stuiver and PJ Reimer

\begin{tabular}{cccc}
\hline Lab. Ref. & $\begin{array}{c}\text { Conventional } \\
\text { age } \\
\left({ }^{\mathbf{1 4}} \mathbf{C} \text { yr BP }\right)\end{array}$ & $\begin{array}{c}\text { Calibrated BP } \\
\text { age ranges }\end{array}$ & $\begin{array}{c}\text { Calibrated age } \\
\text { years BP }\end{array}$ \\
\hline Beta-141048 & $1250 \pm 60$ & $1056-1293$ & 1174 \\
Beta-141049 & $5470 \pm 90$ & $6094-6414$ & 6254 \\
Pta-9162 & $5690 \pm 30$ & $6406-6551$ & 6478 \\
Pta-9163 & $6260 \pm 20$ & $7164-7250$ & 7207 \\
Beta-141050 & $6910 \pm 70$ & $7615-7869$ & 7742 \\
Pta-9166 & $7700 \pm 90$ & $8341-8657$ & 8499 \\
Pta-9165 & $8130 \pm 100$ & $8723-9328$ & 9025 \\
Pta-7892 & $15,700 \pm 220$ & $18,646-19,374$ & 19,010 \\
\hline
\end{tabular}



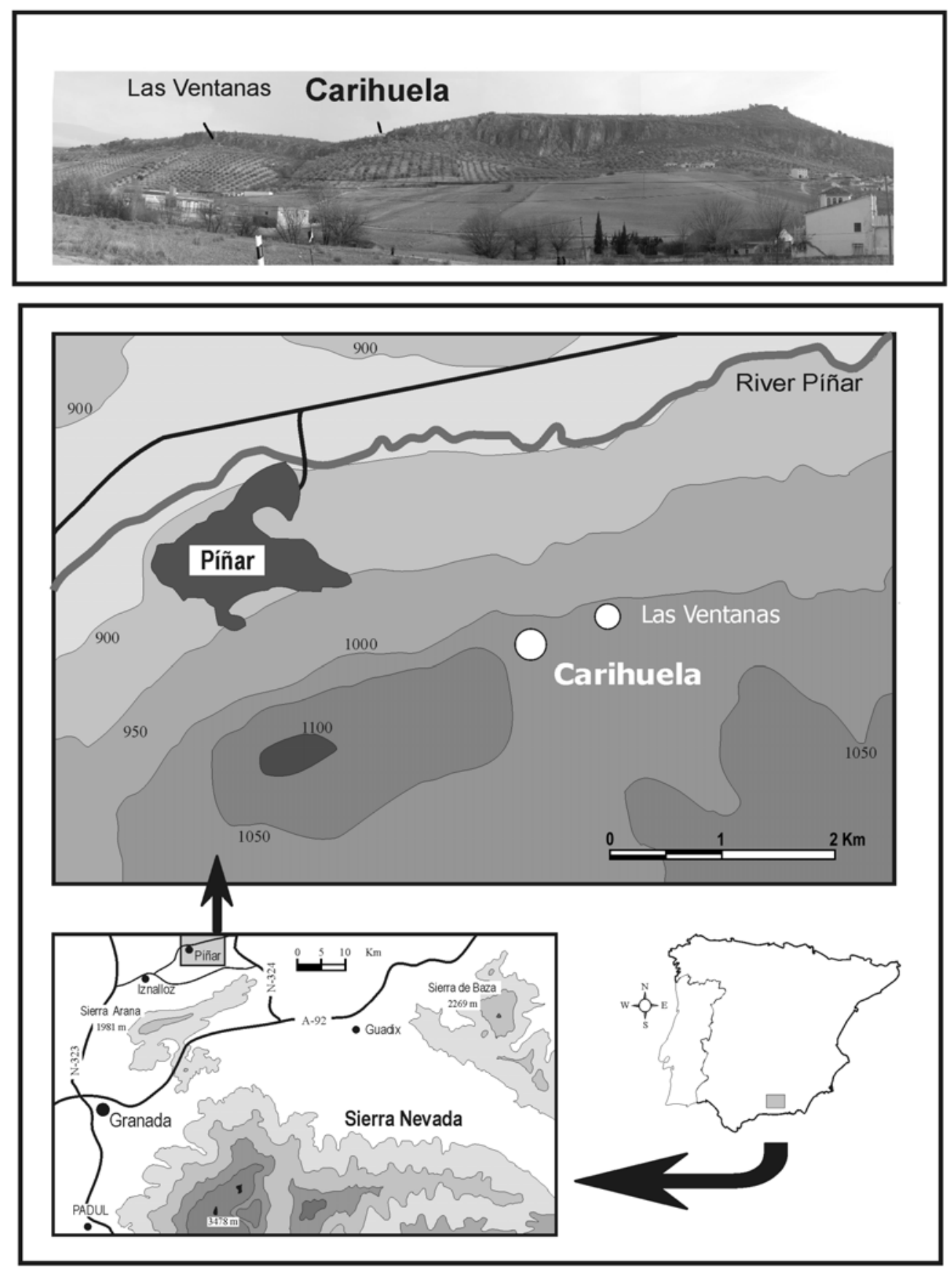

Figure 1 


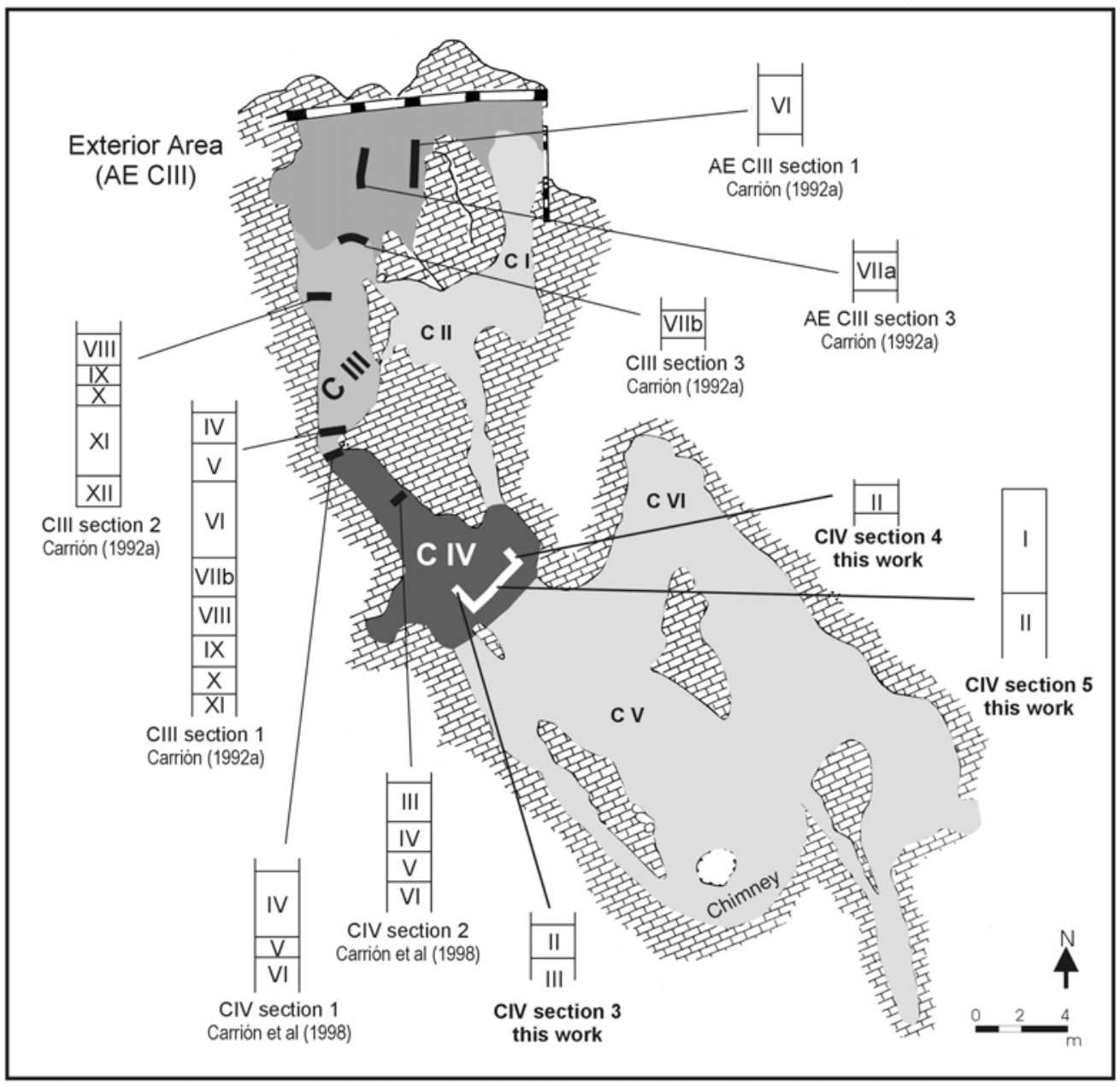

Figure 2 


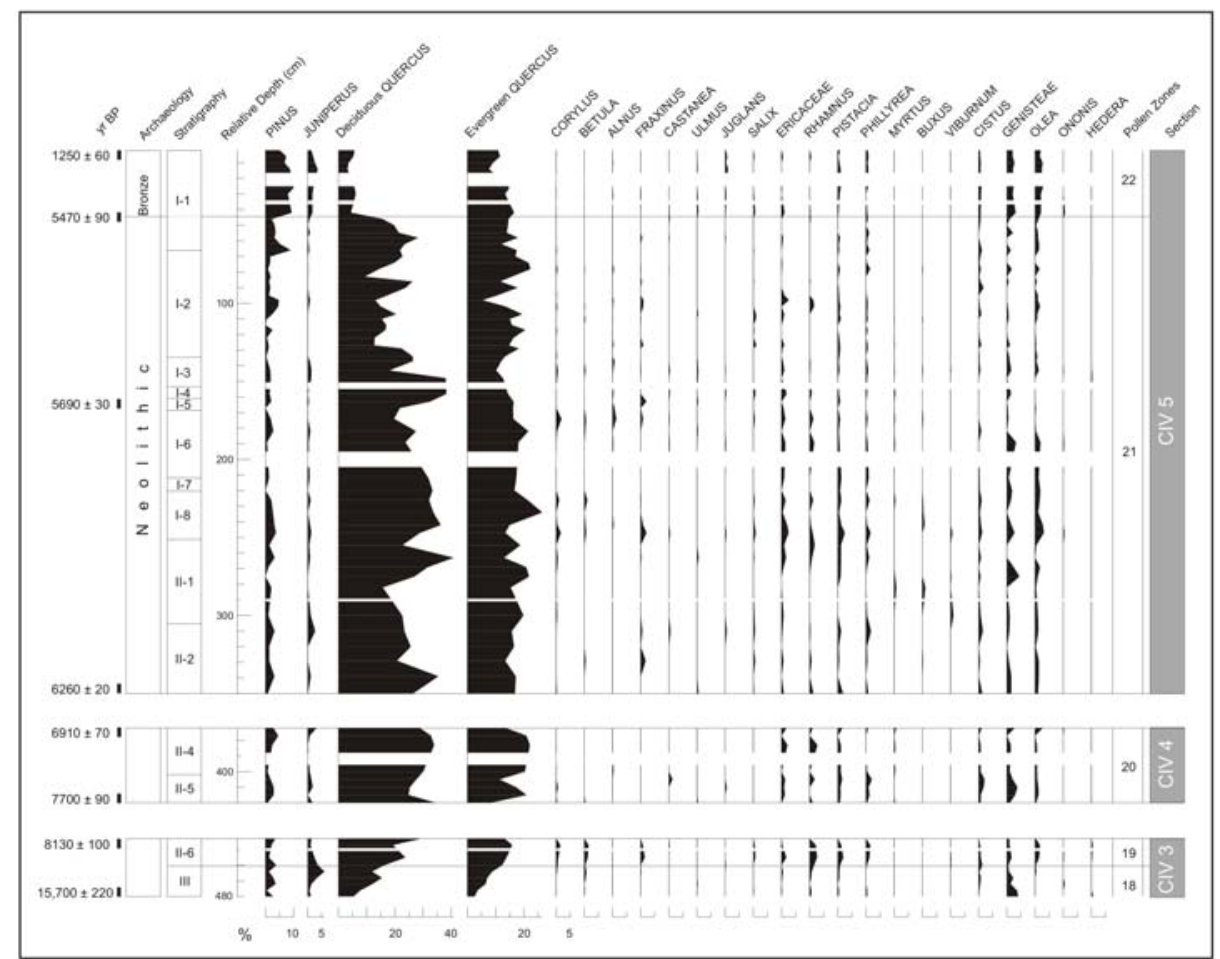

Figure 3 


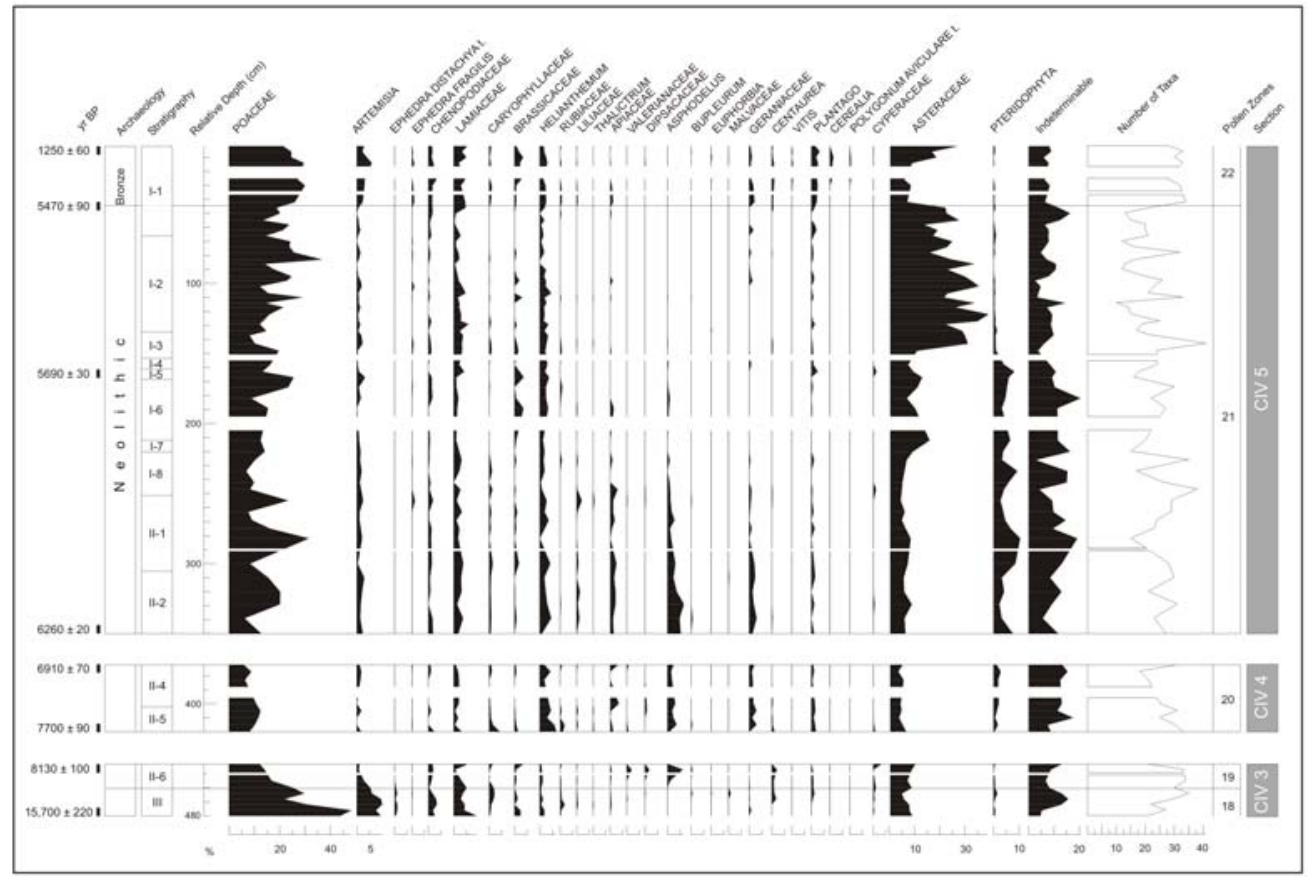

Figure 4 


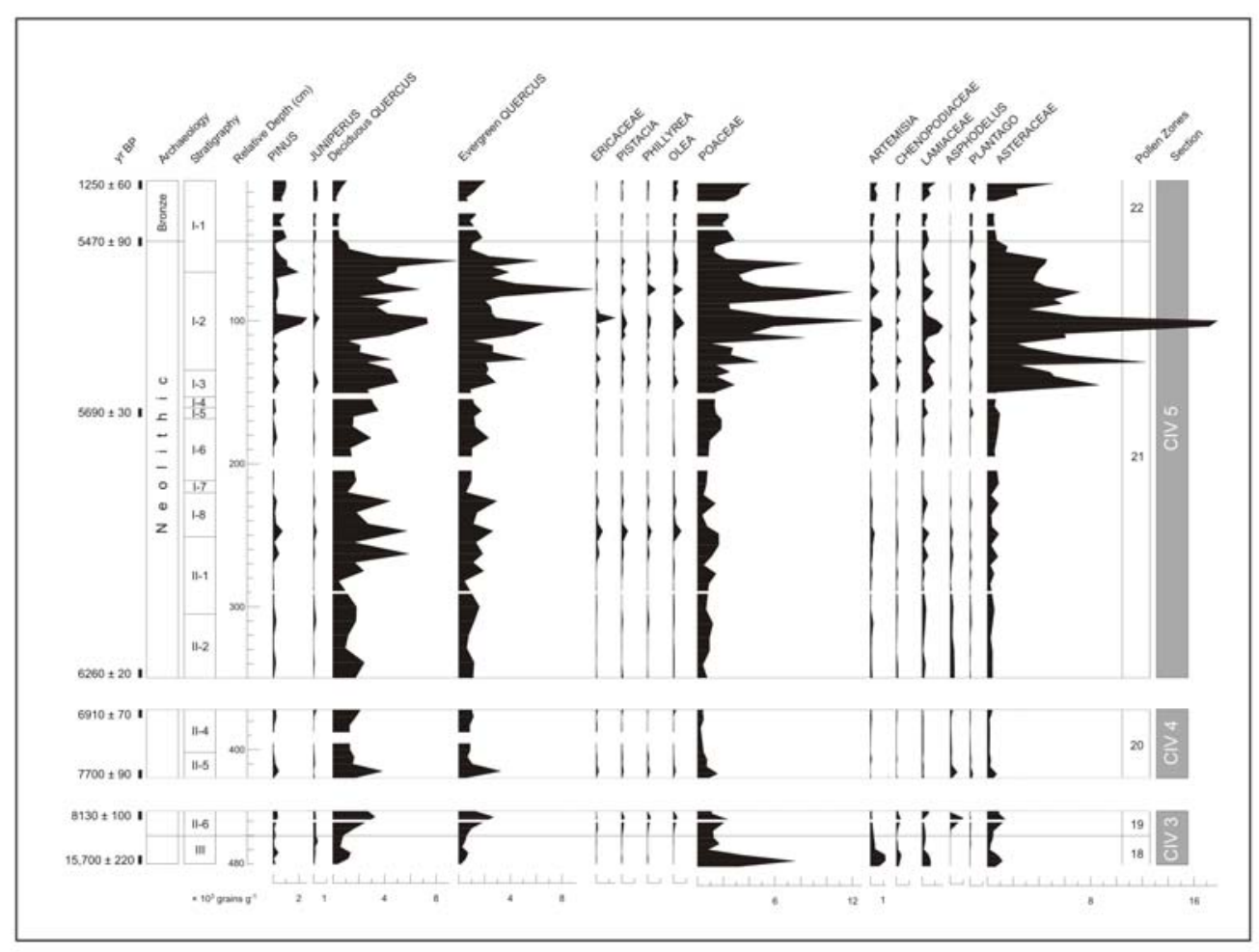

Figure 5

37 


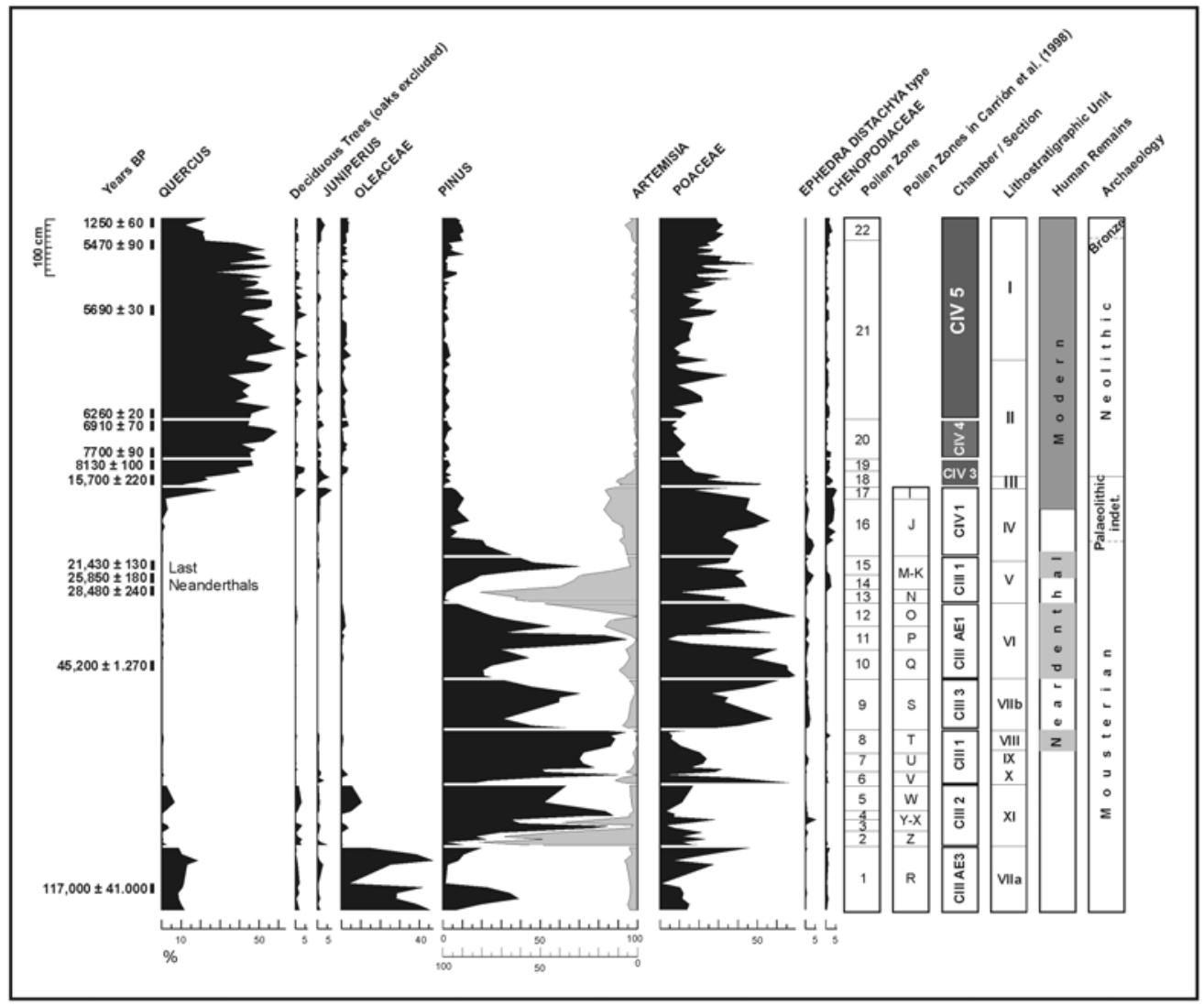

Figure 6 


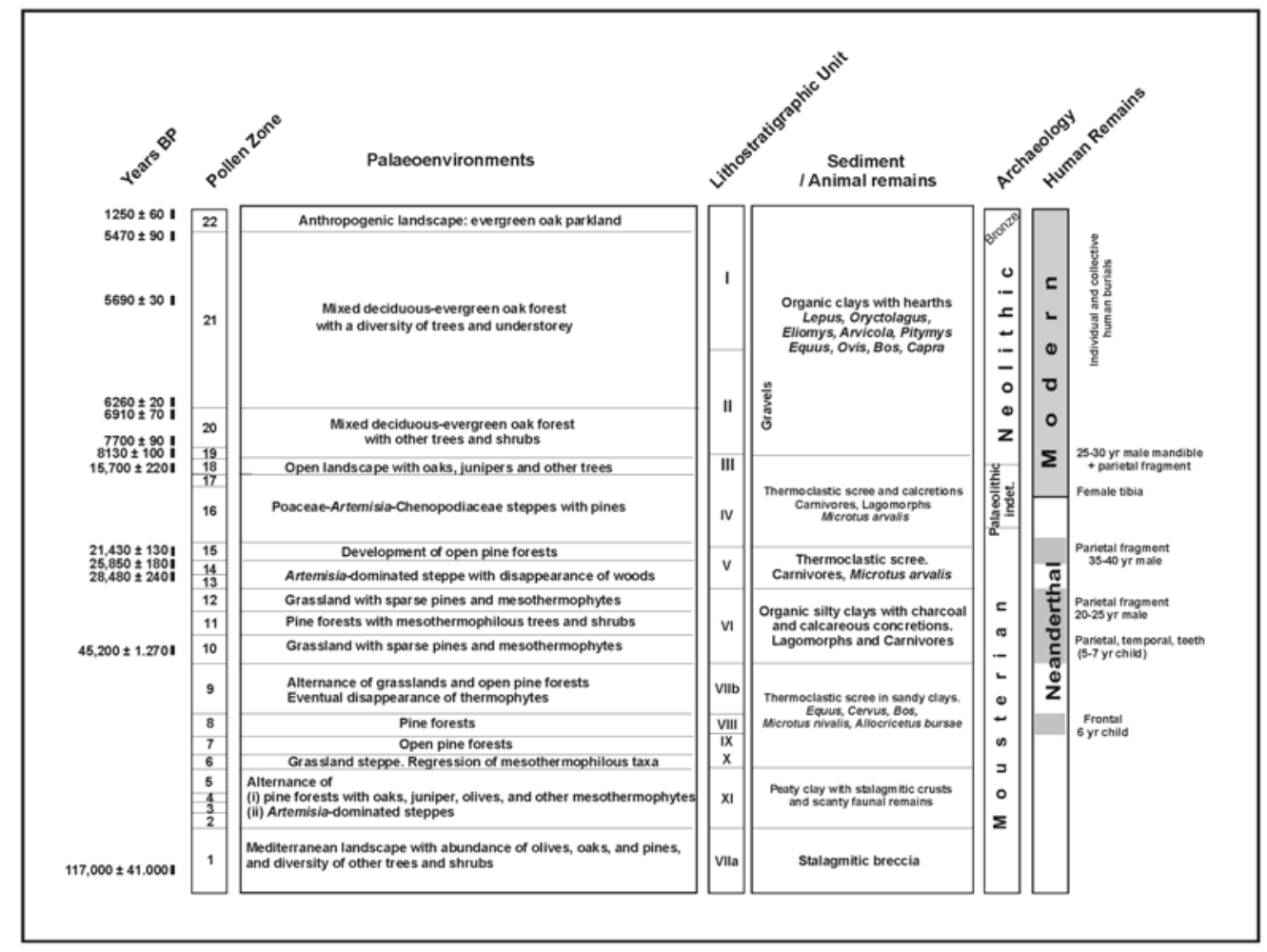

Figure 7 


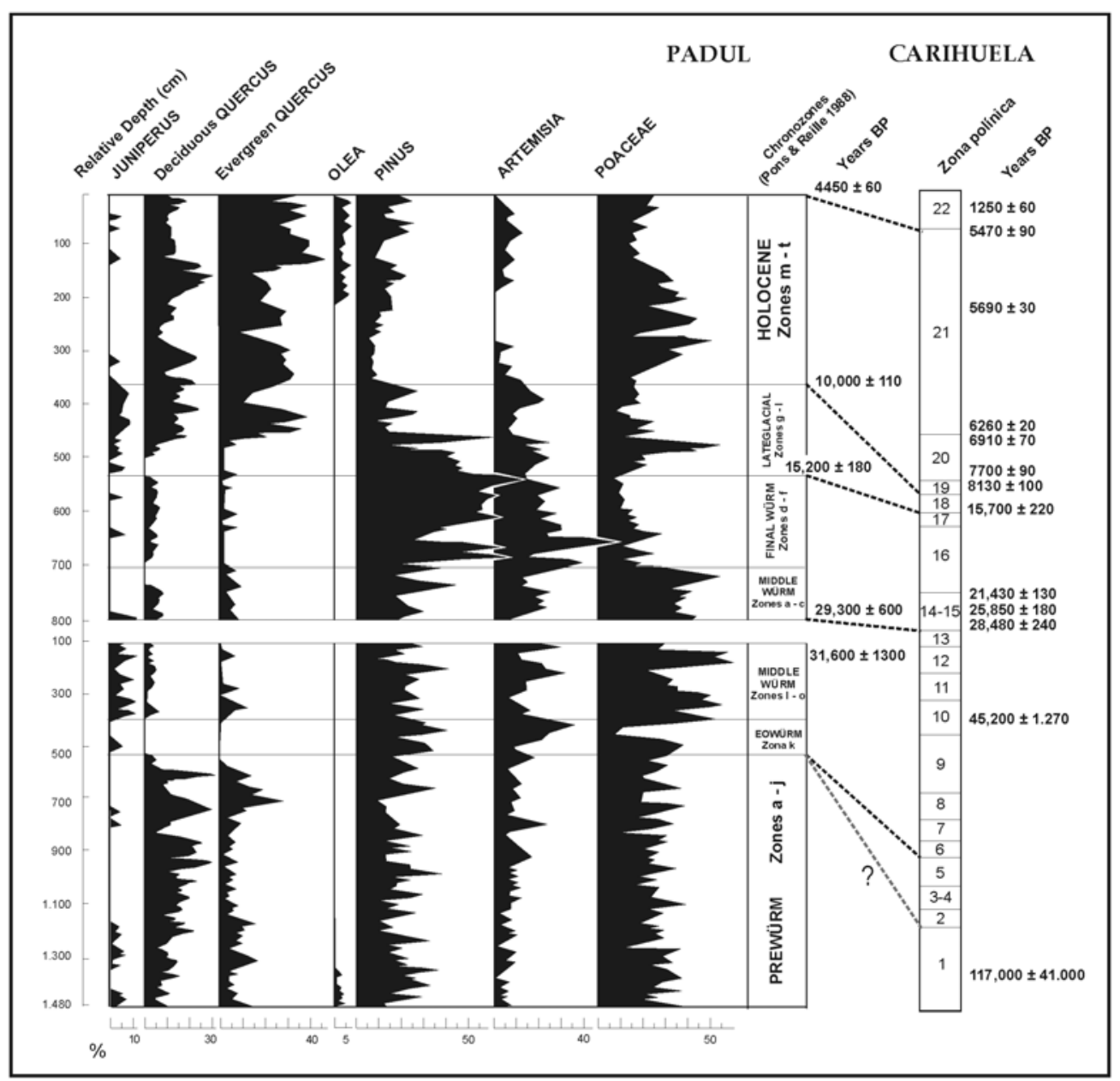

Figure 8 